\title{
PENGEMBANGAN KURIKULUM KKNI PADA MATAKULIAH KONVERSI ENERGI LISTRIK
}

\author{
Abrar Tanjung $^{1,2}$, Jalius Jama ${ }^{2}$, Nizwardi Jalinus ${ }^{2}$, Vivi Efrianova ${ }^{2}$ \\ 1 Fakultas Teknik Universitas Lancang Kuning \\ 2. Fakultas Teknik Universitas Negeri Padang \\ Correspponding author e-mail abrar@unilak.ac.id
}

\begin{abstract}
Abstrak
Mata kuliah Konversi Energi Listrik berbasis Kerangka Kualifikasi Nasional Indonesia untuk memperbaiki kompetensi dan karakter mahasiswa Capaian Pembelajaran (Learning Objective) Lulusan Prodi Teknik Elektro Universitas Lancang Kuning Pekanbaru kemudian dijabarkan ke dalam sejumlah Capaian Pembelajaran (Learning Objective) yang menggambarkan pencapaian setiap lulusan selama proses studi. Pencapaian pembelajaran ini kemudian menjadi dasar kemampuan kerja sesuai dengan bidang studi dan jenjang pendidikan yang terintegrasikan dengan level Kerangka Kualifikasi Nasional Indonesia (KKNI) untuk penddikan tinggi. Model pendekatan penelitian digunakan pendekatan penelitian kualitatif, pendekatan Kualitatif adalah penelitian yang digunakan meneliti pada kondisi objek ilmiah dengan permasalahan yang dinamis, dimana peneliti merupakan sebagai instrumen kunci. sifatnya eksploratif.
\end{abstract}

Kata Kunci : Kurikulum KKNI, Konversi energi listrik, Manajemen kurikulum

Abstract

Electrical Energy Conversion Course based on the Indonesian National Qualification Framework to improve the competency and character of students Learning Objectives Graduates of Electrical Engineering Study Program at Lancang Kuning University in Pekanbaru are then elaborated into a number of Learning Objectives that describe the achievements of each graduate during the study process. This learning achievement then becomes the basis of work ability in accordance with the field of study and level of education which is integrated with the level of the Indonesian National Qualification Framework (KKNI) for high education. The research approach model used is a qualitative research approach, the Qualitative approach is research that is used to examine the conditions of scientific objects with dynamic problems, where the researcher is a key instrument. explorative in nature.

Keywords: KKNI curriculum, electric energy conversion, curriculum management

\section{Pendahuluan}

Kurikulum berbasis Kerangka

Kurikulum Nasional Indonesia (KKNI) merupakan kurikulum perubahan daru kurikulum berbasis kompetensi. Kurikulum berbasis kompetensi ini masih mempunyai kelemahan dalam pembelajaran mahaisswa, model pembelajaran yang digunakan menggunakan pembelajaran secara teoritis. Mahasiswa tidak bisa mengembangkan materi pembelajaran karena terbatas dengan cara pembelajaran dengan penyampaian materi secara teori. Sedangkan pembelajaran dengan menggunakan kurikulum berbasis KKNI, mahasiswa dapat meningkatkan system pembelajaran yang lebih baik. Selain pembelajaran secra teoritis, mahasiswa juga dapat mengembangkan pembelajaran secara praktek. Sehingga mahasiswa dapat meningkatkan skill dan ketrampilan melalui 
praktek lapangan. Praktek lapangan yang di lakukan dengan cara mehaasiswa harus memasuki dunia usaha dan industri secara langsung untuk dapat meningkatkan skill dan kemampuan mahasiswa dalam bidang ilmu pengetahuannya [1][4].

Mata kuliah Konversi Energi Listrik merupakan salah satu mata kuliah yang di pakai pada program studi teknik elektro fakultas teknik Universitsa lancang kuning pada semester empat (4). Mata kuliah konversi energi listrik merupakan salah satu matakuliah kejuruan yang memberikan materi pembelajaran dengan cara teoritis dan praktek. Sehingga dapat menambah wawasan ilmu pengetahuan serta menambah skill dan keterampilan. Mata kuliah ini berisikan materi tentang sumber energi, sistem penggerak mula, pembangkit energy listrik, energy altyernative, energy baru terbarukan dan konservasi lingkungan [2][3]. Buku Konversi energi listrik merupakan sumber belajar yang sangat penting karena setiap tenaga pendidik yang mengajar baik di Program Studi Teknik Elektro menggunakan buku sebagai bahan mata kuliah utama yang diajarkannya di kelas. Buku mata kuliah merupakan bahan yang berasal dari hasil analisis standar kompetensi dan kompetensi. Hasil observasi terhadap Buku Mata kuliah Konversi Energi Listrik Program Studi Teknik Elektro ternyata menunjukkan bahwa selama ini materi hanya menyangkut hal-hal umum dan tidak menyangkut tentang komptetensi kelulusan mahasiswa. Penelitian pada mata kuliah Konversi Energi Listrik pada mahasiswa khususnya Konatif mahasiswa, melakukan analisis data buku-buku tentang kompetensi kelulusan yang sesuai dengan materi yang ada pada standar kompetensi dan kompetensi dasar Konversi Energi Listrik dengan memperkaya informasi, melalui aktivitas dalam analisis data secara interaktif dan berlangsung terus menerus sampai tuntas, sehingga datanya jenuh, sepanjang tidak menghilangkan data aslinya. Aktivitas analisis data yaitu reduksi data, penyajian data, dan verifikasi data. Data harus dilakukan uji validitas (keabsahan data) yaitu uji dengan triangulasi, uji Transferability, uji Auditability, uji Confirmability [4][10]

\section{Metodologi Penelitian}

Metode penelitian yang dilakukan dengan menganalisis beberapa buku Konversi Energi Listrik Program Studi Teknik Elektro yang dilakukan oleh mahasiswa program studi Program Studi Teknik Elektro. Hasilnya buku Program Studi Teknik Elektro mulai dari masing masing mahasiswa ternyata kurang memuat secara sistematis penyanpaian tiap materi karena adanya penjelasan mengenai pengertian yang kurang dari materi itu. Penilaian pengembangan mata kuliah konversi energy listrik yaitu :

a. Bagaimana sistematis/struktur teori yang ada selama ini dalam buku mata kuliah Konversi Energi Listrik Program Studi Teknik Elektro?

b. Bagaimana cara pengembangan sistematis/struktur teori dalam buku mata kuliah Program Studi Teknik Elektro?

c. Bagaimana cara pengembangan sistematis/struktur teori dalam buku mata kuliah Konversi Energi Listrik Program Studi Teknik Elektro berdasarkan Kompetensi Kelulusan?

d. Apakah dengan pengembangan sistematis/struktur teori buku mata kuliah Konversi Energi Listrik Program Studi Teknik Elektro dapat meningkatkan pemahaman dan hasil belajar Program Studi Teknik Elektro serta model pembelajaran?

e. Bagaimana peningkatan berpikir kritis peserta didik dengan adanya materi Konversi Energi Listrik 
Program Studi Teknik Elektro berdasarkan Kompetensi Kelulusan?

Buku mata kuliah yang akan diteliti adalah buku mata kuliah Konversi Energi Listrik (KEL) Program Studi Teknik Elektro. Alur Penelitian:

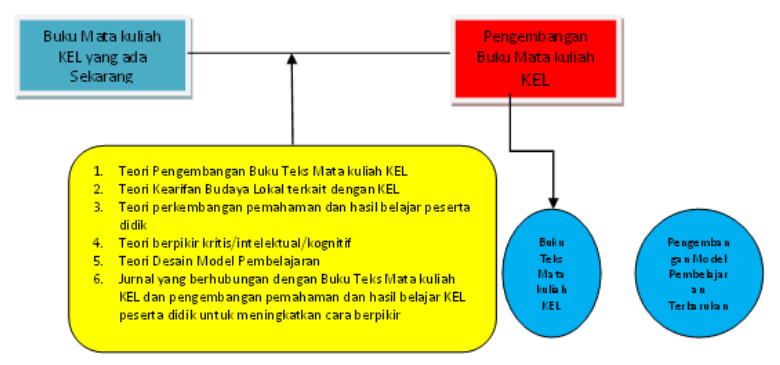

Gambar 1. Bagan Alir Penelitian

Proses pengembangan perubahan kurikulum dan pengembangan kurikulum mata kuliah konversi energi listrik mempunyai perubahan dari kurikulum lama berbasis kompetensi menjadi kurikulum berbasis Kerangka Kurikulum nasional Indonesia (KKNI). Perubahan yang terjadi dari mata kuliah konversi energy listrik terletak pada penyajian materi pembelajaran silabus atau kurikulum. Pada gambar 1 di perlihatkan perubahan mata kuliah konversi energi listrik menggunakan kurikulum lama berbasis kompetensi terjadi pengembangan pada buku mata kuliah konversi energi listrik dengan menggunakan kurikulum berbasis KKNI. Pada pengembangan buku mata kuliah konversi energy lsitrik berbasis KKNI di sajikan materi pembelajaran dengan cara teoritis menambahkan materi pembelajaran kearifan budaya lokal, mahaiswa berpikir secara kritis/intelektual/kognitif serta mahaiswa mempelajari artikel jurnal yang berhubungan dengan materi pembelajaran mata kuliah konversi energy listrik dan di haruskan untuk membuat artikel yang di terbitkan pada sebuah jurnal. [9][5].

\section{Analisa dan Pembahasan}

Model pendekatan penelitian digunakan pendekatan penelitian kualitatif, pendekatan Kualitatif adalah penelitian yang digunakan meneliti pada kondisi objek ilmiah dengan permasalahan yang dinamis, dimana peneliti merupakan sebagai instrumen kunci. sifatnya eksploratif [8][7]. Penelitian dilakukan dengan cara melakukan pengembangan buku mata kuliah, desain model pembelajaran, dan kompetensi kelulusan yang akan direduksi menghasilkan sebuah teori baru pengembangan buku mata kuliah khususnya buku mata kuliah Konversi Energi Listrik Program Studi Teknik Elektro dan Model Pembelajaran baru. Pengembangan buku mata kuliah yang baru dan model pembelajaran yang baru dengan mengikutsertakan Kompetensi Kelulusan Program Studi Teknik Elektro Universitas Lancang Kuning Pekanbaru diharapkan mampu menjawab kekurang mampuan tenaga pendidik dalam menjelaskan secara detail tentang materi yang telah disepakati sehingga mampu meningkatkan pemahamam, berpikir kritis, dan hasil belajar peserta didik. Identifikasi kebutuhan masyarakat terhadap lulusan. Langkah awal dalam menyusun kurikulum adalah melakukan identifikasi terhadap berbagai harapan masyarakat terkait keberadaan Program studi Teknik Elektro Universitas Lancang Kuning Pekanbaru, termasuk identifikasi terhadap berbagai kebutuhan yang diperlukan oleh masyarakat mengenai lulusan yang akan dihasilkan. Tujuan identifikasi agar seluruh aktifitas pendidikan yang diselenggarakan oleh Program studi Teknik Elektro Universitas Lancang Kuning Pekanbaru sesuai dengan harapan masyarakat dan lulusan yang dihasilkan dapat diterima di masyarakat karena memiliki capaian pembelajaran (learning objective) yang sesuai dengan tuntutan masyarakat.

Perumusan Capaian Pembelajaran (Learning Objective) Lulusan Prodi Teknik 
Elektro Universitas Lancang Kuning Pekanbaru kemudian dijabarkan ke dalam sejumlah Capaian Pembelajaran (Learning Objective) yang menggambarkan pencapaian setiap lulusan selama proses studi. Pencapaian pembelajaran ini kemudian menjadi dasar kemampuan kerja sesuai dengan bidang studi dan jenjang pendidikan yang terintegrasikan dengan level Kerangka Kualifikasi Nasional Indonesia (KKNI) untuk penddikan tinggi [2][7]. Masingmasing capaian pembelajaran kemudian dibreakdown dalam kemampuankemampuan yang bersifat teknis sesuai dengan level KKNI [9][10]. Capaian pembelajaran sebagai gambaran utuh setiap lulusan disertai dengan kemampuan teknis dalam menangani suatu pekerjaan atau masalah sesuai level KKNI. Analisis Perkiraan Beban Satuan Kredit Semester (SKS) 1) mata kuliah konversi energi listrik berkaitan dengan waktu satu kegiatan pembelajaran, tanpa dikaitkan dengan variabel lain [10]. Penentuan SKS dilakukan dengan melihat bahan kajian suatu mata kuliah konversi energi listrik atau "keluasan" mata kuliah dan tipe penguasaan atau "kedalaman" mata kuliah dalam bentuk mengingat, memahami, menerapkan, menganalisis, menilai, atau menciptakan. Dari perhitungan keluasan bahan kajian dan tipe kedalaman mata kuliah kemudian dikalikan dengan beban mata kuliah maka akan ketemu beban SKS sebuah mata kuliah konversi energi listrik.

Sistem perkuliahan yang di lakukan pada mata kuliah konversi energy listrik dengan cara sistem kredit semester. Setelah diperoleh perkiraan besarnya SKS mata kuliah konversi energi listrik, maka langkah selanjutnya memetakan level masing-masing mata kuliah berdasarkan scope penggunanya, memetakan komposisi mata kuliah berdasarkan kategori kompetensinya (kompetensi utama atau kompetensi pendukung / pilihan), dan memetakan sequence mata kuliah dalam semester Langkah berikutnya adalah memetakan sequence mata kuliah atau menyusun mata kuliah tersebut di dalam semester [5].

Penyusunan materi mata kuliah berdasarkan logika keilmuannya sampai di semester akhir yang merupakan mata kuliah lanjutan. Pola pembelajaran yang terpusat pada dosen seperti yang di-praktekkan pada saat ini kurang memadai untuk mencapai tujuan pendidikan berbasis kompetensi [6]. Pengembangan mata kuliah Konversi Energi Listrik berbasis KKNI dapat mempengaruhi kualitas mahasiswa dalam penambahan skill dan keterampilan serta pembelajaran secara praktik. Pengembangan kurikulum berbasis KKNI juga dapat merubah cara pandang mahasiswa dalam memmahami dan membahas materi pembelajaran dengan cara edukasi di lapangan baik di dunia usaha maupun dunia industri. Mahasiswa akan dapat mengembangkan materi pembelajaran di perguruan tinggi dengan melakukan pembelajaran di dunia usaha dan dunia industry. [7].

\section{Kesimpulan}

Perumusan Capaian Pembelajaran (Learning Objective) Lulusan Prodi Teknik Elektro Universitas Lancang Kuning Pekanbaru kemudian dijabarkan ke dalam sejumlah Capaian Pembelajaran (Learning Objective) yang menggambarkan pencapaian setiap lulusan selama proses studi. Pencapaian pembelajaran ini kemudian menjadi dasar kemampuan kerja sesuai dengan bidang studi dan jenjang pendidikan yang terintegrasikan dengan level Kerangka Kualifikasi Nasional Indonesia (KKNI) untuk penddikan tinggi. Model pendekatan penelitian digunakan pendekatan penelitian kualitatif, pendekatan Kualitatif adalah penelitian yang digunakan meneliti pada kondisi objek ilmiah dengan permasalahan yang dinamis, dimana peneliti merupakan sebagai instrumen kunci. sifatnya 
eksploratif. Data yang diperoleh dari hasil observasi partisipatif, hasil wawancara tidak terstruktur (hanya dilakukan pencatatan), hasil pemotretan, cuplikan tertulis dari dokumen, catatan lapangan, disusun peneliti dilokasi penelitian, tidak dituangkan dalam bentuk dan bilangan statistik.

\section{Daftar Pustaka}

[1] Djemari Mardapi 2003. "Kerangka dasar pengembangan kurikulum berbasis kompetensi". Makalah disampaikan pada semiloka pengembangan model pembelajaran berbasis kompetensi bagi dosen UNY, tanggal 29 dan 30 September 2003. Yogyakarta: UNY.

[2] Dwi Rahdiyanta, 2003, Kurikulum Berbasis Kompetensi, Seminar Nasional Implementasi KBK di FTUNY, tanggal 11-12 Agustus 2003.

[3] Everard, K.B Geoffrey Morris, dan Ian Wilson. 2004. Effective School Management, London: Paul Chapman Publishing
[4] Saylor J.G. dan kawan-kawan. 1981. Curriculum development and design (second edition). Sidney: Allen \& Unwin.

[5] Nurul Huda, 2017, Manajemen Pengembangan Kurikulum, Jurnal Manajemen Pendidikan Islam, Volume 1 No. 22017

[6] Ornstein, A.C. and Hunkins, F.P. 2009. Curriculum: Foundations, Principles, and Issues (5th ed). Boston: Pearson Education.

[7] Arifin, Zainal. 2016. Konsep dan Model Pengembangan Kurikulum. Bandung: Remajarosdakarya

[7] Fattah, Nanang. 2013. Analisis Kebijakan Pendidikan, Bandung: Remaja Rosdakarya.

[8] Hamalik, Oemar. 2008. Manajemen Pengembangan Kurikulum, Bandung: Remajarosdakarya.

[9] Wahyuddin, 2014. Menejemen Kurikulum, Bandung: Remaja Rosdakarya

[10] Undang-undang No. 20 Tahun 2003 tentang Sistem Pendidikan Nasional 